Victoria Strilets,

Ph.D.,

Higher Educational Institution of Ukoopspilka «Poltava University of Economics and Trade»

Poltava, Ukraine

Nina Rudenko,

Senior Teacher,

Higher Educational Institution of Ukoopspilka «Poltava University of Economics and Trade»

Poltava, Ukraine

\title{
METHOD OF DELPHI AS AN INNOVATIVE TOOL FOR MANAGING ASYMMETRIC INFORMATION IN FINANCIAL RELATIONSHIPS OF POTENTIAL INVESTORS AND SMALL BUSINESS ENTITIES
}

The problem of information asymmetry is a key obstacle in attracting external investment into small businesses. Especially important is management of asymmetricity of the information of the primary awareness about the investment climate of the small business at the stage of the search by the investor of a perspective project for funding. Among other sources of information, international rankings are important tools for minimizing asymmetric information, but their realism and reliability need to be checked. It is identified in the work that some ratings characterize Ukraine as a high-risk and non-contributing country for investing, at the same time, the other ratings create an attractive image of Ukraine. For determining the submissions of such ratings the article proposes an experiment on the STUDY of the conformity of indicators of international rankings to the real state and availability of financial support of small business. The results of the experiment highlight the importance of international rankings as a source for information about the investment attractiveness of small business, but conducted by the method of Delphi survey of experts with many years of experience in the field of small business, allows us to identify significant discrepancy between their scoring of respondents and indicators of ranks, stated in the reports of international organizations. Application of the coefficient of concordance in determining the consistency of opinion of the surveyed experts allowed to obtain reliable data for the making future government decisions. Based on the obtained results and the visualization of the existing information asymmetry in the financial interaction of a potential investor and a small business, the directions of asymmetric information management and proposed measures to minimize the risks associated with the limited and inaccurate information are substantiated.

Keywords: financial provision, small business, Delphi method, international rankings, small business investment, coefficient of concordance.

Introduction. The Eurointegration orientation of Ukraine opens up new opportunities and prospects for small business, along with this the actual problem of their financial support is upgraded because, in order to compete in the European market, it is necessary to meet its quality standards, which entails significant monetary injection for activity improvement. Given the limited equity capital for doing business, the possibility of attracting funds from foreign investors is becoming the most attractive prospect of financial security. However, the problem of informational asymmetry in the financial interaction of an actual or potential investor and a small business arises in the process of implementing an investment project as a result of lack of unified information bases, significant costs of obtaining information, unreliability, 
incompleteness and non-transparence of information provided to investors. The insufficient volume of received information carries great risks and reduces the willingness of investors to invest in the early stage of financing business projects.

Literature review. The ability of firms to access capital from different sources depends primarily on the degree of information asymmetry faced by investors [3]. The phenomenon of information asymmetry has been studied in detail by foreign scientists. Thus, for the first time, the presence of the fact of the informational superiority of some subjects of interaction with others was described in the scientific works of American scholars Akerlof G.A., Spence M. and Stiglitz J., who determined that information possessed by the subjects of financial relations is deformed: business executives are more informed than potential investors, while shareholders and factual investors define the goal of organization through the prism of personal interests $[1 ; 10 ; 11]$. Akerlof G.A. argued that the availability of asymmetric information could lead to withdrawal from the market of those investors who seek to avoid risk [1]. Spence M. and Stiglitz J. proved that the elimination of information asymmetry positively affects the final results of business entities activities [10; 11]. In addition, J. Stiglitz emphasized the fact that it is sometimes advantageous for participants of financial relations to use incomplete information. In particular, when the information asymmetry in combination with the wrong choice of organizational chart contributes to the implementation of unattractive projects, while promising projects are rejected [11, p. 214]. When information resources are asymmetric it prevents the optimal allocation of resources [5].

Sceral M., Erkoyuncua J. A., Shehab E. define information asymmetry as a situation in which the relevant actors have different levels and quality of information on project or contract execution [9]. Dehlen T., Zellweger T., Kammerlander N., Halter F. argue that information asymmetry occurs when the knowledge of the project of one side is less than the other due to the concealment of genuine intentions and anticipated actions by the counterparty [4]. Usually, these asymmetries arise either as a result of the confidentiality of useful information or intentional deception and the provision of insufficient information [2].

Among the Ukrainian scientists, there is also a number of scientists who have tried to investigate the problem and the consequences of asymmetric information. So, Mikhailovska O.V. emphasizes the fact that as well as any asymmetries, asymmetries in the information space will affect the decision of investors in the aspect of choosing regions and investment objects, so the study of such influence is important not only from the theoretical, but also from a practical point of view, so as for each country, regardless of its level of development, attracting the maximum amount of foreign investment flows is one of the priority tasks [18, c. 21]. Babichenko V.V. notes that the asymmetry of information arising in financial relations leads to an increase in transaction costs, and at the level of government-voters relations - to abuse of power and neglect of the principles of economic efficiency and social justice [13, p.187]. Kravchuk G.V. draws attention to the fact that information asymmetry and its consequences lead to the deformation of the market mechanism, casting doubt on the fundamental possibility of its effective action, since the basic premise of the classical economic theory - equality of information between the participants of economic relations - is denied Information asymmetry raises the cost of economic activity, and most importantly, from the standpoint of financial security, significantly reduces the level of trust between the participants in financial relations [16].

Sysoyeva L.Yu. highlights a number of specific features defining information asymmetry in the market: the bilateral nature of inadequate disclosure of information; deterioration of the macroeconomic situation; deliberate concealment of true information and creation of "information barriers" as well as various approaches to "selection of information" in the market [21, p. 66]. levdokimov V.V. argues that when the state becomes the main user of information, the company seeks to show the lowest possible financial results in order to reduce the tax base, which leads to low investment attractiveness of enterprises, understatement of the official salary (sometimes to a minimum), accrued and paid to employees, etc. [22, p. 138]. 
The problem of minimization of information asymmetry is still relevant in scientific circles. In particular, S.Ya. Babinskaya has identified number of general measures to neutralize the asymmetry of information such as: market signals (in accordance with the theory of "market signals" by Spence M.), the implementation of state control over the quality of goods and services, involvement in the process of implementing innovative projects of banks and venture companies [12, p. 6]. A team of authors led by Kravchuk G.V. allocates, among the methods of combating information asymmetry, Spens' theory of market signals, along with alternative methods such as application of instruments of business entities (sanctions, property pledges, debt contracts, etc.); methods of state regulation; methods of informational nature of origin (for example, creation of various specialized databases (credit and insurance stories, registers of automobile and other violations, etc.) [16, c. 215-217]. In this case, a number of authors $[17 ; 19]$ believe that the presence of international ratings in the investment climate of the country also significantly reduces information asymmetry, increases the attractiveness of investment projects, neutralizes the risk of wrong choices being effective tools for eliminating information asymmetry, and a large number of ranking techniques allows an investor to obtain information on all aspects of investment attractiveness of the country. So, Plastun O.L. and Dudkin O.V. noted that the processes of eliminating information asymmetry at the micro level include measures to inform consumers about the characteristics of products and peculiarities of the firm's activities, and at the macro level, the compilation of international ratings assessing investment risks [19, p. 191]. Makarenko O.I. and Pogorily D.V. argue that the ability to reduce moral hazard and unfavorable selection as a manifestation of information asymmetry among financial market participants is a determining feature of international indices that are benchmarks for investors' decision-making in the segment of sustainable investments [17, p. 46]. Information asymmetry is the main cause of distrust of potential investors in the sphere of small business, and the insufficient level of disclosure contained in the financial statements makes it impossible to reflect the real state of the small business sector by the state authorities at the macro level.

Aims. In view of the importance of eliminating information asymmetry in the process of interaction between small business and potential investors, the article aims to conduct an experiment on determining the importance of international ratings in reducing the asymmetry of information as signals of the initial information on the assessment of the feasibility of investing and the study of the completeness, adequacy and feasibility of existing international ratings in the field of financial relations of investors and small business subjects.

Results. Ukraine's access to the European market creates attractive opportunities for attracting foreign investment in financing and development of small business. However, the existence of asymmetric awareness that occurs not only in the process of implementing an investment project but even at the initial stage of the investment climate research, reduces the possibility of obtaining sufficient amount of necessary information to make a positive optimal investment decision (Figure 1).

Agreeing with the opinion of Plastun O.L. and Dudkin O.B. that failure, due to limited resources to fully assess all possible information about potential investment objects, leads to the use of a number of ratings, competitiveness indices, investments and business appeal of countries, regions, companies, which allows investment companies to refine their own forecasts and assessments, and simplifies the adoption of investment decisions [19, p. 192].

The problem is already at the stage of the study of investment attractiveness of the country, which is reflected in the ratings and indices that are calculated by domestic and international organizations and are the first signal criteria of choice. It is quite rightly asserted by Plastun O.L. and Dudkin O.V. that the compilation of international ratings that assess investment risks are designed to eliminate information imbalances at the macro level [19, p. 191], but we believe that there is the possibility of manoeuvring some indicators that are included in the calculation of indices and knowingly distort the realism of rating results. So, given that the Government of Ukraine is now making every effort to get to the European community 
as soon as possible, this process is accompanied by a large number of reforms that at least nominally give the opportunity to raise the country's position in various ratings. As an example, we can highlight some of the tax reform measures to reduce the number of taxes that nominally should have helped reduce the tax burden on business entities, which led to Ukraine's rise in the business ranking. However, in fact, these measures did not have a significant impact on the reduction of tax payments, as a number of taxes were consolidated and consolidated (in particular, land tax and real estate tax were simply merged into one without lowering their rates). In order to prove the validity of the assertion that information asymmetry in the financial interaction between the investor and small business is already at the stage of processing and analysis of the primary information on the favourable economic environment, which is reflected through the prism of the indexes, we suggest an experiment to compare the importance of international ratings with the actual view of Ukrainian small business entities on existing problems and the environment of small businessTo do this, among the existing rating indicators, we have selected those which, in our opinion, enable us to reflect the financial aspect of Ukraine's small business activity and compare them with expert assessments of small business.

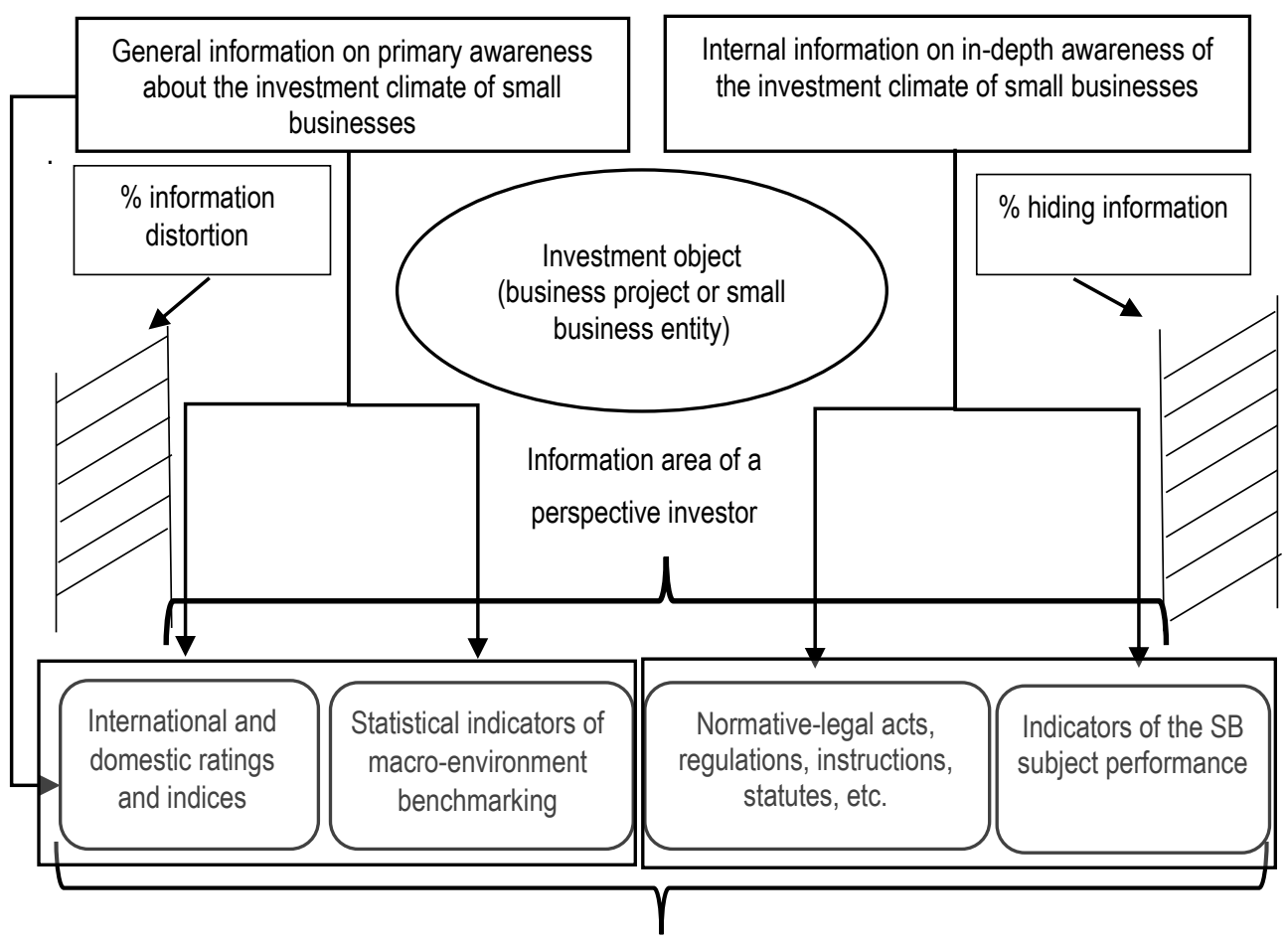

Information area of the subject of small business

Manifestation of information asymmetry

Figure 1 - Theoretical representation of asymmetric information of a potential investor and a small business entity

Thus, among the key indicators of the financial support assessment we have identified the following indicators: the index of ease of doing business (business registration, credit obtaining, protection of 
N. Pedchenko, V. Strilets, N. Rudenko. Method of Delphi as an Innovative Tool for Managing Asymmetric Information in Financial Relationships of Potential Investors and Small Business Entities

minority investors, taxation) and indicators of the index of economic freedom (the index of the legal effectiveness, solving insolvency problems, freedom of investment, financial freedom, government decency) (Table 1).

Table 1 - Indicators of international ratings that enable us to assess the state and benefits of financial support for small businesses in 2018 (compiled by the author based on data [6; 8])

\begin{tabular}{|c|l|c|c|c|}
\hline $\begin{array}{c}\text { Indicator } \\
\text { sequence } \\
\text { number }\end{array}$ & \multicolumn{1}{|c|}{ Indicator } & $\begin{array}{c}\text { Value by 100- } \\
\text { point system, Z }\end{array}$ & $\begin{array}{c}\text { Optimal value, } \\
\text { Op }\end{array}$ & $\begin{array}{c}\text { Normative } \\
\text { values }{ }^{*}, \mathrm{~N}\end{array}$ \\
\hline 1 & Business Registration (1-100) & 91,05 & 100 & 2,75 \\
\hline 2 & Getting a loan 100, incl.. & 75 & 100 & 4,0385 \\
\hline 3 & $\begin{array}{l}\text { Index of protection level of credit } \\
\text { information 0-12 - }\end{array}$ & 8 & 12 & 0,12 \\
\hline 4 & Coverage of the credit bureau(0-100) & 47,3 & 100 & 0,03053 \\
\hline 5 & Minority investor protection100 & 55 & 100 & 0,09772 \\
\hline 6 & Taxation 100, incl. & 80,77 & 100 & 2,34375 \\
\hline 7 & Payments (quantity per year) the best - 3 & 5 & 3 & 1,412 \\
\hline 8 & $\begin{array}{l}\text { Time (quantity per year) } \\
\text { the best - 50 }\end{array}$ & 327,5 & 50 & 3,135 \\
\hline 9 & Total tax rate and deductions (\% of profit) & 37,8 & 18,47 & 1,75 \\
\hline 10 & $\begin{array}{l}\text { The index of the effectiveness of the } \\
\text { regulatory framework }\end{array}$ & 7,5 & 16 & 1,5 \\
\hline 11 & Solving insolvency problems & 28,24 & 100 & 1,45 \\
\hline 12 & Freedom of business & 62,7 & 100 & 2,75 \\
\hline 13 & Investment freedom & 35 & 100 & 4,0385 \\
\hline 14 & Financial freedom & 30 & 100 & 0,12 \\
\hline 15 & Governmental decency & 29 & 100 & 0,03053 \\
\hline
\end{tabular}

Note. Transfer to a 5-point rating system to compare with experts' assessments

As can be seen from the table, indicators of the ease of doing business characterize Ukraine as a sufficiently developed state in a business environment with favourable taxation and lending conditions. At the same time, according to the index of economic freedom in 2018, Ukraine ranked low (150th out of 180 countries), and the report evaluated the status of economic freedom in Ukraine as "predominantly unfree". So we agree with the opinion of the scientists that Ukraine's positions in various international ratings form an extremely unattractive image and, accordingly, investors consider it to be too risky and unattractive for investing in the country [19, p.198].

In order to determine the extent to which the information provided is asymmetric in relation to the vision of the situation by small business entities, we conducted a survey among 14 small business representatives in different fields of activity, and asked to evaluate the indicators outlined in Table 1 using the scale from 0 to 5 ( 0 - the worst indicator, and 5 is the best indicator). In order to obtain reliable results and to exclude the probability of errors in the results due to the possible low skills of the experts, the survey was conducted by the Delphi method, which consists of carrying out systematic questioning of qualified experts, mathematical and statistical processing of the respondents' responses, correction of experts by their estimates on the basis of each processing cycle. The main idea of the method is to obtain mutually agreed (consensus) conclusions of a group of experts regarding one or more interrelated characteristics of the system of interest [20, p.17]. As the group of authors Kurtov A.I., Polikashin O.V., Potichensky A.I., V.M. Aleksandrov correctly notes the Delphi method is characterized by such features as the anonymity of expert opinions; regulated feedback, carried out by the analytical group; group response which is formed by statistical methods reflecting general opinion of the experts [15, p.119]. 
The procedure for questioning and obtaining the results of an expert assessment of the state and the availability of financial support for small businesses in Ukraine by the Delphi method is shown in Figure 2.

Stages
Identification of the key indicators
and enable us to assess the state
for small businesses

Figure 2 - Gradual procedure for determining the asymmetry of information between potential investors and business entities regarding the state and availability of financial support of small businesses in Ukraine (author's development)

When choosing experts for questioning, the participants were selected with deep knowledge and experience in the field of small business, which allowed to obtain an objective comprehensive assessment of the actual state of small business and to increase the efficiency and reliability of the results.

The processing of the experts' data is based on the ranking of the data importance. Each score given by the $i$-th expert is expressed in natural numbers, with the sum of the $S j$ ranks estimated by the experts and $j$-th characteristic $(j=1,2 \ldots m$ ) expressed by the formula:

$$
S_{j}=\sum_{i=1}^{n} R_{i j}
$$

where Rij is a rank of evaluation given by the $i$-th expert to the $j$-th characteristic; $n$ is a number of experts. 
N. Pedchenko, V. Strilets, N. Rudenko. Method of Delphi as an Innovative Tool for Managing Asymmetric Information in Financial Relationships of Potential Investors and Small Business Entities

Based on the results of the questionnaire we formed a rank matrix (Table 2)

Table 2 - Matrix of estimation ranks of indicators characterizing the state and favourable financial support of small business in Ukraine (calculated by the author)

\begin{tabular}{|c|c|c|c|c|c|c|c|c|c|c|c|c|c|c|c|c|c|}
\hline \multirow{2}{*}{$\begin{array}{l}\text { Indicato } \\
\text { rs }\end{array}$} & \multicolumn{14}{|c|}{ Experts } & \multirow{2}{*}{$\begin{array}{c}\text { Sum of } \\
\text { ranks, } S j\end{array}$} & \multirow{2}{*}{$\begin{array}{c}\text { Deviation from } \\
\text { the average } \\
\text { amount, dj }\end{array}$} & \multirow[b]{2}{*}{ dj2 } \\
\hline & 1 & 2 & 3 & 4 & 5 & 6 & 7 & 8 & 9 & 10 & 11 & 12 & 13 & 14 & & & \\
\hline 1 & 2 & 3 & 2 & 1 & 1 & 1 & 3 & 2 & 3 & 2 & 2 & 0 & 2 & 2 & 26 & $-7,87$ & 61,88 \\
\hline 2 & 4 & 5 & 4 & 4 & 3 & 3 & 4 & 5 & 3 & 4 & 5 & 4 & 4 & 5 & 57 & 23,13 & 535,15 \\
\hline 3 & 4 & 4 & 3 & 4 & 4 & 5 & 5 & 4 & 3 & 3 & 3 & 5 & 4 & 4 & 55 & 21,13 & 446,62 \\
\hline 4 & 1 & 2 & 3 & 2 & 1 & 2 & 3 & 3 & 2 & 2 & 1 & 2 & 1 & 1 & 26 & $-7,87$ & 61,88 \\
\hline 5 & 1 & 2 & 3 & 1 & 1 & 1 & 2 & 3 & 3 & 2 & 1 & 2 & 2 & 3 & 27 & $-6,87$ & 47,15 \\
\hline 6 & 2 & 1 & 2 & 3 & 3 & 3 & 2 & 1 & 4 & 4 & 5 & 5 & 2 & 2 & 39 & 5,13 & 26,35 \\
\hline 7 & 4 & 4 & 5 & 5 & 5 & 4 & 4 & 3 & 3 & 4 & 5 & 3 & 4 & 5 & 58 & 24,13 & 582,42 \\
\hline 8 & 2 & 2 & 1 & 1 & 1 & 3 & 1 & 2 & 1 & 2 & 1 & 1 & 2 & 2 & 22 & $-11,87$ & 140,82 \\
\hline 9 & 1 & 1 & 0 & 0 & 1 & 2 & 2 & 2 & 1 & 1 & 1 & 1 & 2 & 1 & 16 & $-17,87$ & 319,22 \\
\hline 10 & 0 & 0 & 2 & 3 & 3 & 1 & 1 & 2 & 3 & 2 & 2 & 3 & 3 & 2 & 27 & $-6,87$ & 47,15 \\
\hline 11 & 2 & 3 & 4 & 3 & 3 & 4 & 2 & 3 & 4 & 4 & 3 & 2 & 2 & 3 & 42 & 8,13 & 66,15 \\
\hline 12 & 1 & 1 & 1 & 0 & 0 & 0 & 1 & 1 & 0 & 2 & 3 & 1 & 1 & 0 & 12 & $-21,87$ & 478,15 \\
\hline 13 & 4 & 4 & 3 & 5 & 4 & 3 & 3 & 5 & 5 & 3 & 3 & 5 & 3 & 2 & 52 & 18,13 & 328,82 \\
\hline 14 & 3 & 2 & 2 & 3 & 3 & 2 & 4 & 2 & 3 & 1 & 3 & 4 & 2 & 1 & 35 & 1,13 & 1,28 \\
\hline 15 & 0 & 1 & 2 & 1 & 2 & 1 & 1 & 1 & 2 & 0 & 0 & 2 & 1 & 0 & 14 & $-19,87$ & 394,68 \\
\hline Total & - & - & - & - & - & - & - & - & - & - & - & - & - & - & 508 & $x$ & 3538 \\
\hline $\begin{array}{l}\text { Averag } \\
\text { e value }\end{array}$ & - & - & - & - & - & - & - & - & - & - & - & - & - & - & 33,867 & $x$ & $X$ \\
\hline
\end{tabular}

Given the small sample size of respondents, an assessment of the degree of opinions consistency is no less important for the scientific substantiation of the forecast by expert methods. The final conclusion for a decision on the choice of the most acceptable factor is possible only with a certain level of experts consensus. [14, c.98]. Therefore, for the scientific substantiation of the forecast and carring out the second round of Delphi, the degree of expert opinions consistency was estimated using the coefficient of concordance (formula 2).

$$
\text { Ccon }=\frac{120 \sum_{j=1}^{n} d_{j}^{2}}{m^{2}\left(n^{3}-n\right)-m \sum_{i=1}^{m} T i}
$$

where d=Sj-Smed, a Smed $=\sum \mathrm{Sj} / \mathrm{n}, T_{i}=\sum_{e=1}^{L}\left(t_{e}^{3}-t_{e}\right)$ is calculated in the presence of equal ranks (n-number of groups of equal ranks, te-number of equal ranks in each group, L-number of groups of related ranks (of the same rank) [20, p 98].

Output data for calculating the coefficient of concordation are given in Table 3. 
Table 3-Output data for calculating the coefficient of concordance (calculated by the author)

\begin{tabular}{|l|c|c|c|}
\hline \multicolumn{1}{|c|}{ Experts } & Number of related groups (of the same rank) & $\begin{array}{c}\text { Number of equal ranks } \\
\text { in each group }\end{array}$ & $\Sigma T_{i}$ \\
\hline 1 expert & $(4 ; 4) ;(1 ; 1)$ & 2 & 6 \\
\hline 2 expert & $(2 ; 2)$ & 1 & 0 \\
\hline 3 expert & $(3 ; 3 ; 3)$ & 1 & 0 \\
\hline 4 expert $\mathrm{T}$ & $(4 ; 4) ;(3 ; 3)$ & 2 & 6 \\
\hline 5 expert & $(1 ; 1) ;(1 ; 1) ;(3 ; 3)$ & 1 & 0 \\
\hline 6 expert & - & 0 & 0 \\
\hline 7 expert & $(2 ; 2)$ & 1 & 0 \\
\hline 8 expert & $(3 ; 3) ;(2 ; 2 ; 2)$ & 2 & 6 \\
\hline 9 expert & $(3 ; 3 ; 3) ;(1 ; 1)$ & 2 & 6 \\
\hline 10 expert & $(2 ; 2) ;(4 ; 4)$ & 2 & 6 \\
\hline 11 expert & $(1 ; 1) ;(5 ; 5) ;(1 ; 1) ;(3 ; 3 ; 3 ; 3)$ & 4 & 60 \\
\hline 12 expert & $(2 ; 2) ;(1 ; 1)$ & 2 & 6 \\
\hline 13 expert & $(4 ; 4) ;(2 ; 2) ;(2 ; 2)$ & 3 & 24 \\
\hline 14 expert & - & 0 & 0 \\
\hline$\Sigma$ & 25 & $\mathrm{X}$ & 120 \\
\hline $\mathrm{m}$ & 14 & $\mathrm{X}$ & $\mathrm{X}$ \\
\hline $\mathrm{n}$ & 15 & $\mathrm{X}$ & $\mathrm{X}$ \\
\hline
\end{tabular}

Count the results of the intermediate calculations, substituting the formula for the coefficient of concordance.

$$
\text { Ccon }=\frac{120 \sum_{j=1}^{n} d_{j}^{2}}{m^{2}\left(n^{3}-n\right)-m \sum_{i=1}^{m} T i}=\frac{120 \times 3538}{14^{2}\left(15^{3}-15\right)-14 \times 120}=0,646
$$

The obtained concordation coefficient testifies inconsistency in the opinions of experts since full consistency of opinions is achieved with the coefficient of concordance 1, and in our case, it is much smaller, it is necessary to increase it by eliminating the points of the expert whose thoughts negatively affects the generalized consistency of the group. To do this, we calculate the coefficients of concordation with the sequential exclusion of one of the experts (Table 4).

Table 4 - Concordance coefficient calculated by successive exclusion of one of the experts (calculated by the author)

\begin{tabular}{|c|c|c|c|c|c|}
\hline \multirow[b]{2}{*}{$\begin{array}{c}\text { Exclusion } \\
\text { of an } \\
\text { expert }\end{array}$} & \multirow[b]{2}{*}{$\begin{array}{c}\text { Concordance } \\
\text { coefficient }\end{array}$} & \multirow[b]{2}{*}{$\begin{array}{l}\text { Significance of coefficient } \\
\text { of concordance on } \\
\text { Pearson's criterion }\end{array}$} & \multicolumn{3}{|c|}{ Pearson's Table value } \\
\hline & & & $\begin{array}{c}\text { at a level of } \\
\text { significance } \\
0.95 \\
\end{array}$ & $\begin{array}{c}\text { at a level of } \\
\text { significance } \\
0,975 \\
\end{array}$ & $\begin{array}{c}\text { at a level of } \\
\text { significance } \\
0,99 \\
\end{array}$ \\
\hline 1 & 2 & 3 & 4 & 5 & 6 \\
\hline 1 & 0,601 & 10,92173196 & \multirow{8}{*}{$>6,573$} & \multirow{8}{*}{$>5,63$} & \multirow{8}{*}{$>4,66$} \\
\hline 2 & 0,614 & 11,15150515 & & & \\
\hline 3 & 0,634 & 11,52060481 & & & \\
\hline 4 & 0,585 & 10,63538144 & & & \\
\hline 5 & 0,608 & 11,05143643 & & & \\
\hline 6 & 0,617 & 11,20538832 & & & \\
\hline 7 & 0,630 & 11,45094158 & & & \\
\hline 8 & 0,633 & 11,49674227 & & & \\
\hline
\end{tabular}


N. Pedchenko, V. Strilets, N. Rudenko. Method of Delphi as an Innovative Tool for Managing Asymmetric Information in Financial Relationships of Potential Investors and Small Business Entities

Table 4

\begin{tabular}{|c|c|c|c|c|c|}
\hline 1 & 2 & 3 & 4 & 5 & 6 \\
\hline 9 & 0,646 & 11,7276701 & \multirow{6}{*}{$>6,573$} & \multirow{6}{*}{$>5,63$} & \multirow{6}{*}{$>4,66$} \\
\hline 10 & 0,634 & 11,51290722 & & & \\
\hline 11 & 0,664 & 12,06059107 & & & \\
\hline 12 & 0,621 & 11,28890722 & & & \\
\hline 13 & 0,686 & 12,46779381 & & & \\
\hline 14 & 0,600 & 10,90556701 & & & \\
\hline
\end{tabular}

Consequently, the exclusion of the ninth, eleventh and thirteenth experts positively influences the consistency of expert opinions. On the contrary, the exclusion of the first and last expert reduces the overall consistency of the entire group. In this case, calculate the coefficient of concordation after the exclusion of experts to confirm the hypothesis of their negative impact on the consistency of assessments in the group:

$$
\text { Ccon }=\frac{120 \sum_{j=1}^{n} d_{j}^{2}}{m^{2}\left(n^{3}-n\right)-m \sum_{i=1}^{m} T i}=\frac{120 \times 3198,6}{11^{2}\left(15^{3}-15\right)-11 \times 30}=0,944
$$

As can be seen from the results of the calculation the consistency of the estimates has increased significantly (from 0,646 to 0,944 ) which confirms the need for a new group of experts in the number of 11 respondents (Table 5).

Table 5-Results of the poll in the second round of the Delphi method

\begin{tabular}{|c|c|c|c|c|c|c|c|c|c|c|c|c|c|c|c|c|}
\hline \multirow{2}{*}{$\begin{array}{l}\frac{\infty}{0} \\
\frac{0}{0} \\
\stackrel{\varpi}{4}\end{array}$} & \multicolumn{12}{|c|}{ Experts } & \multirow{2}{*}{$\begin{array}{l}\text { Sum of } \\
\text { ranks, } S j\end{array}$} & \multirow{2}{*}{$\begin{array}{l}\text { Deviation from } \\
\text { the average } \\
\text { amount, dj }\end{array}$} & \multirow{2}{*}{ dj2 } & \multirow{2}{*}{$\begin{array}{l}\text { Weighted } \\
\text { score }\end{array}$} \\
\hline & 1 & 2 & 3 & 4 & 5 & 6 & 7 & 8 & 9 & 10 & 12 & 14 & & & & \\
\hline 1 & 2 & 3 & 2 & 1 & 1 & 1 & 3 & 2 & 3 & 2 & 0 & 2 & 22 & $-11,87$ & 140,82 & 1,57 \\
\hline 2 & 4 & 5 & 4 & 4 & 3 & 3 & 4 & 5 & 3 & 4 & 4 & 5 & 48 & 14,13 & 199,75 & 3,43 \\
\hline 3 & 4 & 4 & 3 & 4 & 4 & 5 & 5 & 4 & 3 & 3 & 5 & 4 & 48 & 14,13 & 199,75 & 3,43 \\
\hline 4 & 1 & 2 & 3 & 2 & 1 & 2 & 3 & 3 & 2 & 2 & 2 & 1 & 24 & $-9,87$ & 97,35 & 1,71 \\
\hline 5 & 1 & 2 & 3 & 1 & 1 & 1 & 2 & 3 & 3 & 2 & 2 & 3 & 24 & $-9,87$ & 97,35 & 1,71 \\
\hline 6 & 2 & 1 & 2 & 3 & 3 & 3 & 2 & 1 & 4 & 4 & 5 & 2 & 32 & $-1,87$ & 3,48 & 2,29 \\
\hline 7 & 4 & 4 & 5 & 5 & 5 & 4 & 4 & 3 & 3 & 4 & 3 & 5 & 49 & 15,13 & 229,02 & 3,50 \\
\hline 8 & 2 & 2 & 1 & 1 & 1 & 3 & 1 & 2 & 1 & 2 & 1 & 2 & 19 & $-14,87$ & 221,02 & 1,36 \\
\hline 9 & 1 & 1 & 0 & 0 & 1 & 2 & 2 & 2 & 1 & 1 & 1 & 1 & 13 & $-20,87$ & 435,42 & 0,93 \\
\hline 10 & 0 & 0 & 2 & 3 & 3 & 1 & 1 & 2 & 3 & 2 & 3 & 2 & 22 & $-11,87$ & 140,82 & 1,57 \\
\hline 11 & 2 & 3 & 4 & 3 & 3 & 4 & 2 & 3 & 4 & 4 & 2 & 3 & 37 & 3,13 & 9,82 & 2,64 \\
\hline 12 & 1 & 1 & 1 & 0 & 0 & 0 & 1 & 1 & 0 & 2 & 1 & 0 & 8 & $-25,87$ & 669,08 & 0,57 \\
\hline 13 & 4 & 4 & 3 & 5 & 4 & 3 & 3 & 5 & 5 & 3 & 5 & 2 & 46 & 12,13 & 147,22 & 3,29 \\
\hline 14 & 3 & 2 & 2 & 3 & 3 & 2 & 4 & 2 & 3 & 1 & 4 & 1 & 30 & $-3,87$ & 14,95 & 2,14 \\
\hline 15 & 0 & 1 & 2 & 1 & 2 & 1 & 1 & 1 & 2 & 0 & 2 & 0 & 13 & $-20,87$ & 435,42 & 0,93 \\
\hline Total & - & - & - & - & - & - & - & - & - & - & - & - & 435 & $X$ & 3041,3 & $X$ \\
\hline $\begin{array}{c}\text { Average } \\
\text { value }\end{array}$ & - & - & - & - & - & - & - & - & - & - & - & - & 29 & $X$ & $X$ & $X$ \\
\hline
\end{tabular}

The statistical truthfulness of the value of the concordation factor is determined by the $X_{p}^{2}$ Pearson's criterion (formula 6): 


$$
X_{p}^{2}=\frac{12 \sum_{j=1}^{n} d_{j}^{2}}{\left[m n \times(n+1)-\frac{1}{n-1} \times \sum_{i=1}^{m} T i\right]}
$$

Thus, according to our calculations:

$$
X_{p}^{2}=\frac{12 \times 3538}{\left[14 \times 15 \times(15+1)-\frac{1}{15-1} \times 30\right]}=12,64
$$

The calculated $X_{p}^{2}$ value is compared with the table $X_{p m m a}^{2}$ value for $\mathrm{n}-1$ degrees of freedom and confidence probability $(\mathrm{P}=0.95$ or $\mathrm{P}=0.99)$. If $X_{p}^{2}>X_{p m m a}^{2}$, then the coefficient of concordation is true, but if $X_{p}^{2}<X_{p m m a}^{2}$, then it is necessary to increase the number of experts. For the given case with 15-1 degrees of freedom and $\mathrm{P}=0,95 X_{p m m a}^{2}=5,63$, а для $\mathrm{P}=0,99 X_{p m m a}^{2}=4,66$. In both cases $X_{p}^{2}>X_{p m m a}^{2}$, hence, the coefficient of concordation is statistically significant, which indicates the sufficiency of the number of respondents interviewed to obtain a realistic concerted result.

Questioning for the second round of Delphi has already taken place in terms of the number of 11 experts and provided an opportunity for a balanced and coherent evaluation of the indicators of the state and availability of financial support of small businesses in Ukraine given by experts. The results obtained in the second round formed the basis for comparative calculations with the data of international ratings and enabled identify information asymmetry (Figure 3 ) in assessment of business registration procedure, mechanism of taxation, level of business freedom; government decency, protection of minority investors (according to the data of expert assessment the indicators of the state and availability of financial security by financial business entities is lower than that stated in international ratings).

At the same time, according to such indicators as freedom of investment, solving insolvency and financial freedom, respondents 'assessments are higher than those reported in international organizations' reports.

In general, such a construction of a graphical data image allowed in the process of general analysis to determine the need to minimize information asymmetry and outline its promising directions. So, taking into account the achievements of scientists and leading economists of our time, we have identified the following directions of reduction of information asymmetry regarding the state and availability of financial support of small business in Ukraine:

1) creation of a unified information base for small business entities that are open to foreign investment;

2) increasing the quality and availability of the credit history databases, insurance history bureau, and exchange information;

3) improving the quality of state policy in the field of business regulation, combating corruption and bribery;

4) holding trainings on financial literacy and providing advisory assistance on the procedure of attracting investments.

5) providing information by small business entities in English in order to expand its range of users;

6) full automation of financial reporting to tax authorities in order to increase access to its use;

7) using services of an independent auditor, even when there are no relevant requirements from the government regulations;

8) overcoming moral hazard through the close interaction of entrepreneurs and investors in the 
process of concluding contracts.

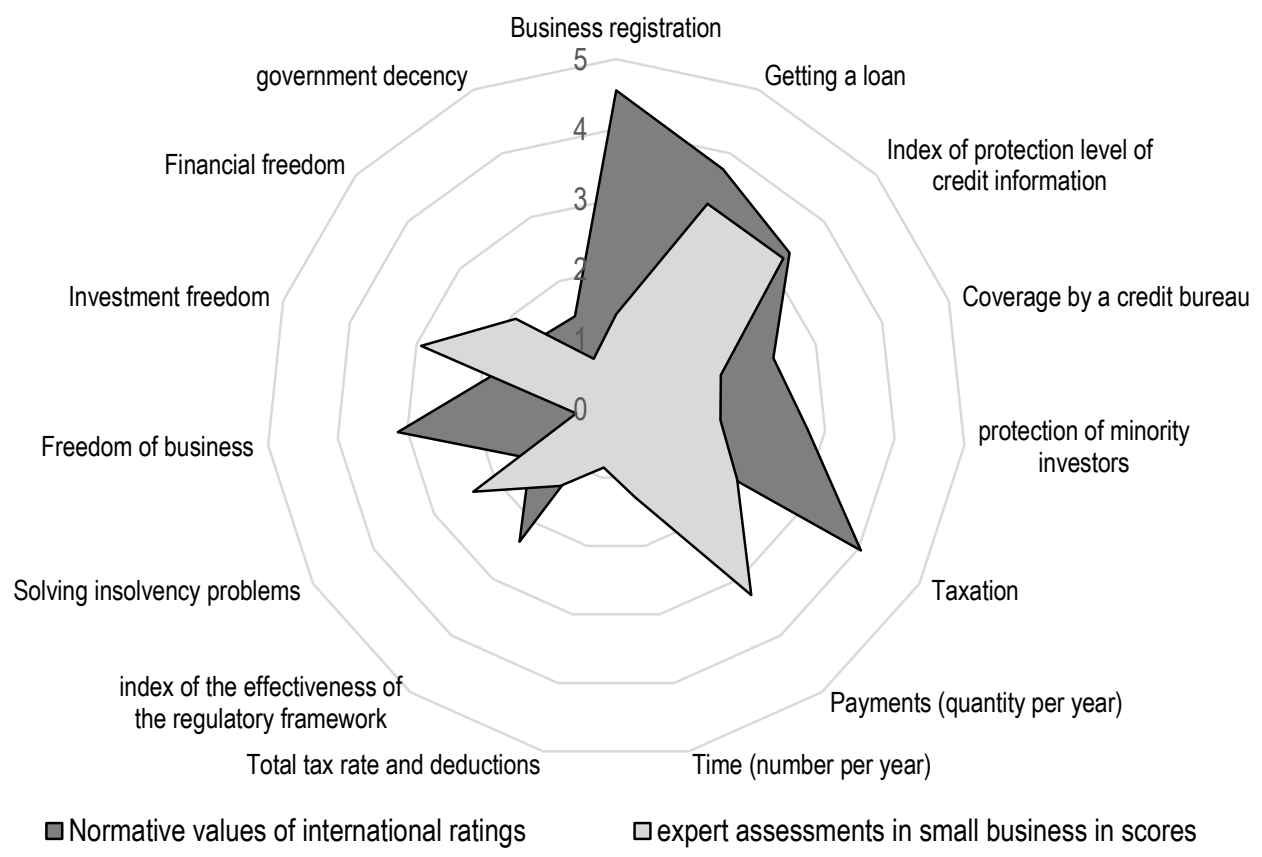

Figure 3 - Graphical depiction of the existing information asymmetry between the indicators of international ratings and expert assessments in the sphere of small business in Ukraine (developed by the author)

Conclusion. Consequently, the paper identifies the causes and consequences of information asymmetry in the financial support of small businesses. An experiment that was conducted allowed to determine the asymmetry of information between a potential investor and small business entity at the initial stage of the investment climate research.

The results of the survey, the consistency and feasibility of which was achieved through the use of the Delphi method, allowed to justify the directions of minimizing the risks associated with the limited and inaccurate information. The directions for further research are the development of practical recommendations for ensuring the strategy of minimizing information asymmetry.

1. Akerlof A. George (1970). The Market for "Lemons": Quality Uncertainty and the Market Mechanism / The Quarterly Journal of Economics, № 84, p. 488-500.

2. Clarkson G., Jacobsen T.E., Batcheller A.L. (2007). Information asymmetry and information sharing. Government Information Quarterly. -Available at: DOl:10.1016/j.giq.2007.08.001

3. Cumming E/ Douglas J., and Sofia A. Johan (2013). Venture capital and private equity contracting: An international perspective/-Available at https://books.google.com.ual

4. Dehlen T., Zellweger T., Kammerlander N., Halter F.(2014) The role of information asymmetry in the choice of entrepreneurial exit routes/ Journal of Business Venturing. Volume 29, Issue 2, P.193-209

5. Do Quy Toan (2004). Asymmetric Information book chapter in The Social Science Encyclopedia 2nd editvion. Adam Kuper and Jessica Kuper (eds.). Available at: https://books.google.com.ua/

6. Doing business 2018: equal opportunity for all/ A world Bank Group Flagship report.- Available at: http://www.doingbusiness.org 
7. Fili A. (2014) Business angel - venture negotiation in the post-investment relationship: the use of the good cop, bad cop strategy/ Venture Capital.-№ 16 (4).- pp. 309-325.

8. Index of economic freedom / The Wall Street Journal in partnership with Heritage Foundation .- Available at http://www.heritage.org/index

9. Mario Sceral, John Ahmet Erkoyuncua, Essam Shehab (2017). Identifying information asymmetry challenges in the defence sector: 6 International Conference on Through-life Engineering Services, Bremen, Germany

10. Michael Spence (1973). Job Market Signaling / Spence Michael // The Quarterly Journal of Economics, V. 87, P. 355-374

11. Stiglitz J., Rothschild M. (1976). Equilibrium in Competitive Insurance Markets: An Essay on the Economics of Imperfect Information / Quarterly Journal of Economics, V. 90, P. 629-650.

12. Babinska S.la (2018). Informatsiine zabezpechennia rozroblennia ta realizatsii innovatsiinykh proektiv [Information support for the development and implementation of innovative projects]. Candidate's thesis. Lviv [in Ukrainian].

13. Babichenko V.V. (2016) Korporatyvni finansy v informatsiinii ekonomitsi: determinanty i prioritety rozvytku v Ukrain [Corporate finances in the informational economy: determinants and priorities of development in Ukraine]: Doctor's thesis. Kyiv [in Ukrainian].

14. Hrabovetskyi B.le. (2010). Metody ekspertnykh otsinok: teoriia, metodolohiia, napriamy vykorystannia [Methods of expert evaluations: theory, methodology, directions of use]. Vinnytsia : VNTU [in Ukrainian].

15. Kurtov A.I., Polikashyn O.V., Potikhenskyi A.I., Aleksandrov V.M. (2017) Ekspertni otsinky. Metod Delfi yak tekhnolohiia pryiniattia upravlinskykh rishen [Expert evaluations. Delphi method as a technology for making managerial decisions] / Zbirnyk naukovykh prats Kharkivskoho natsionalnoho universytetu - Collection of scientific works of Kharkiv National University . -№ 1(50). [in Ukrainian].

16. Kravchuk H.V. (2013) Borotba z informatsiinoiu asymetriieiu yak vazhlyva skladova zabezpechennia finansovoi bezpeky [Fighting information asymmetry as an important component of financial security provision]/ Visnuk Chernihivskoho derzhavnoho tekhnolohichnoho universytetu.- Bulletin of the Chernigiv State Technical University, № 1 (64) [in Ukrainian].

17. Makarenko I.O., Pohorilyi D.V. (2017) Reitynhy kompanii na rynkakh vidpovidalnoho investuvannia yak instrument minimizatsii informatsiinoi asymetrii v umovakh staloho rozvytku [Ratings of companies in responsible investment markets as a too for minimizing information asymmetry under sustainable development] / Konkurentospromozhnist pidpryiemstv $v$ umovakh transformatsiinykh protsesiv v ekonomitsi Ukrainy : zbirnyk materialiv II Mizhvuzivskoi naukovo-praktychnoi konferentsii.Competitiveness of enterprises in the conditions of transformation processes in the economy of Ukraine: a collection of materials of the II Interuniversity scientific and practical conference - Kharkiv : KhTEI KNEU [in Ukrainian].

18. Mykhailovska O.V. (2009) Informatsiini asymetrii $v$ svitovykh investytsiino-innovatsiinykh protsesakh [Information asymmetries in global investment-innovation processes] / Investytsii: praktyka ta dosvid/- Investments: practice and experience, № 6 [in Ukrainian].

19. Plastun O.L., Dudkin O.V. (2012) Mizhnarodni investytsiini reitynhy yak zasib usunennia informatsiinoi asymetrii na makroekonomichnomu rivni [International investment ratings as a means of eliminating information asymmetry at the macroeconomic level] / Marketynh i menedzhment innovatsii/- Marketing and management of innovations, № 3 [in Ukrainian].

20. Popov O.O. (2015) Ekspertni metody ta systemy dlia pryiniattia upravlinskykh rishen: [Expert methods and systems for making managerial decisions]- Available at: irbis-nbuv.gov.ua [in Ukrainian].

21. Sysoieva L.Iu. (2014) Vplyv asymetrii informatsii na rynok bankivskykh posluh [Influence of Asymmetry of Information on the Market of Bank Services ] / Naukovyi visnyk Kharkivskoho derzhavnoho universytetu.- Scientific Bulletin of the Kharkiv State University, №6.4 [in Ukrainian].

22. levdokimov V. V. (n.d.). Asymetriia bukhhalterskoi informatsii ta shliakhy yii minimizatsii [Asymmetry of accounting information and ways to minimize it]. Available at: http://www.vuzlib.com.ua/articles/book [in Ukrainian].

Н. С. Педченко, д.е.н., професор, Вищий навчальний заклад Укоопспілки «Полтавський університет економіки і торгівлі» (Полтава, Україна);

B. Ю. Стрілець, к.е.н., доцент, Вищий навчальний заклад Укоопспілки «Полтавський університет економіки і торгівлі» (Полтава, Україна);

H. С. Руденко, Вищий навчальний заклад Укоопспілки «Полтавський університет економіки і торгівлі» (Полтава Україна).

Метод Дельфі як інноваційний інструмент управління асиметрією інформації у фінансових взаємовідносинах потенційних інвесторів та суб'єктів малого бізнесу

Проблема інформаційної асиметріїє ключовою перешкодою у залученні зовнішніх інвестицій у малий бізнес. Особливо важливим є зменшення асиметрії первинної інсрормації про інвестиційний клімат малого бізнесу на етапі пошуку інвестором перспективного проекту для вкладення коштів. Використання міжнародних рейтингів $є$ важливим інструментом мінімізації асиметрії інформації, проте їх реалістичність та достовірність потребують перевірки. У статті визначено, що одні рейтинги характеризують Україну як високоризикову та непривабливу для інвестування країну, в той час як інші створюють привабливий імідж України. Для визначення рівня обгрунтованості таких рейтингів у статті запропоновано проведення експерименту по дослідженню відповідності індикаторів міжнародних рейтингів 
N. Pedchenko, V. Strilets, N. Rudenko. Method of Delphi as an Innovative Tool for Managing Asymmetric Information in Financial Relationships of Potential Investors and Small Business Entities

реальному стану та доступності фінансового забезпечення малого бізнесу. Результати проведеного експерименту висвітлюють важливість міжнародних рейтингів як джерела отримання інформації про інвестиційну привабливість малого бізнесу, проте проведене методом Дельфі опитування експертів, які мають успішний багаторічний досвід діяльності у сфрері малого підприємництва, дало змогу виявити значну невідповідність між бальними оцінками респондентів та індикаторами рейтингів, заявленими у звітах міжнародних організацій. Застосування коефріцієнту конкордації при визначенні узгодженості думок опитаних експертів дозволило отримати достовірні дані для прийняття майбутніх управлінських рішень. На підставі отриманих результатів та проведеної візуалізації наявної інфоормаційноі асиметрії у фінансовій взаємодії потенційного інвестора та суб'єкта малого бізнесу у статті обгрунтовані напрями управління асиметрією інформації та запропоновані заходи мінімізації ризиків, пов'язаних з обмеженістю і неточністю інформації.

Ключові слова: фінансове забезпечення, малий бізнес, метод Дельфі, міжнародні рейтинги, інвестування в малий бізнес, коефіцієнт конкордації. 